\title{
Experimental Organism Malignant Renal Mesenchymal Tumor
}

National Cancer Institute

\section{Source}

National Cancer Institute. Experimental Organism Malignant Renal Mesenchymal Tumor. NCI Thesaurus. Code C126088.

A malignant neoplasm arising from foci of atypical fibroblast-like cells in the interstitium of the outer stripe of the outer medulla of the kidney. (INHAND) 